\title{
IMPACT OF INFORMATION TECHNOLOGIES' INVESTMENTS ON THE PROFITABILITY OF TUNISIAN BANKS: PANEL DATA ANALYSIS
}

\author{
Syrine Ben Romdhane \\ Assistant Professor \\ High Institute of Management of Tunis \\ University of Tunis, Tunisia \\ E-mail: syrine_br@yahoo.fr
}

\begin{abstract}
This study examines the relationship between Information Technology investment and the profitability of Tunisian banks, via static and dynamic panel regression models. Our study focused on 15 Tunisian banks for 19 years (2001-2019). To assess the profitability of these banks, three measures were used: two traditional accounting ratios and net interest margin. Our research has shown the importance of the role played by IT in Tunisian banks since IT investments improve their profitability. This finding contradicts the "Productivity Paradox" that high IT investments are not associated with better performance. Indeed, Tunisian banks are acting on their size to boost their performance, and the more the banks take the risk by granting more loans, the more profitable they are by increasing their Return on Assets. Finally, public banks are more profitable than private banks when considering their net interest margin.
\end{abstract}

Keywords: Information Technology, Profitability, Banks, Statistic Panel, Dynamic Panel.

JEL Classification Codes: B21, C58, G21, G32, O32.

\section{INTRODUCTION}

Today, in banks, different Information Technologies (IT) has become the key to the financial engineering process for organizations wishing to survive and continue to thrive in this rapidly changing financial environment. The advent of the Internet has revolutionized the world of communication, making it possible to optimize the strategy of globalization advocated by the contemporary vision of the business world. This technological revolution has led to the decompartmentalization of financial markets and necessary deregulation, which has profoundly transformed market structures and forms of competition (Hoque et al., 2020). Financial institutions have not escaped this upheaval and, under the pressure of new technologies and customer expectations, have been forced to change their structure and modify their strategy as well as the conditions of performance. IT is an essential tool that banks must manage and master to ensure their competitiveness. This gives them a privileged place in the banking production process and raises permanent questions about the relevance of their strengthening and the methods of their optimization. A new conception of banking performance then emerges and an appropriate performance evaluation system must be implemented. 
The massive use of IT by banks has created a need to assess its impact on bank profitability. Profitability assessment is a ubiquitous activity proving even more a necessity with any technological change operating within the company (Teru et al., 2017). However, finding suitable analytical tools for these technologies is proving difficult. This has resulted in a lack of empirical validation on the impact of IT on bank profitability.

In this research work, we will attempt to study the impact of IT on the profitability of 15 Tunisian banks for 19 years (from 2001 to 2019). To this end, three parts will be presented: the first will introduce a review of both theoretical and empirical literature. The second will present the hypotheses and the methodology of the research. Finally, the results of the regressions estimated on a static and dynamic panel will be the subject of the third part.

\section{LITERATURE REVIEW}

From the beginning of the 1990s, the various waves of technological innovation have aroused the interest of many economists. However, most of these different studies have focused on the relationship between investments in IT and the increased productivity of firms. Their main hypothesis is as follows: investments in IT provide improvements in productivity, hence management efficiency (Landauer, 1995). With the development of IT, the objectives of firms continued to vary between two poles: improving efficiency and developing market power (Chowdhary, 2017). In the following, we will present a literature review on the effects of IT investments on productivity, then on the evolution of bank profitability.

\section{IT Investments and Productivity}

"We can see computers everywhere except in productivity statistics" (Solow, 1987: 36). This "Productivity Paradox", formulated fifteen years ago by Robert Solow during his speech to receive the Nobel Prize for economics in Stockholm in 1987, has given rise to countless applied studies in the United States as in Europe and has identified the most diverse explanations. What has led Solow to say this famous quote is that numerous studies have shown that investing in IT has little or no impact on productivity. In other words, the massive IT spending over the past two decades did not seem to have any effect on the productivity of its users, either at the micro-level or at the macro level.

Berndt in 1991 was the first theorist to attempt to measure the productivity from IT investments. He relied on the assumption that investments contribute positively to the output measured by the gross marginal profit. His work was followed by that of Loveman (1994) and Morrison and Berndt (1990) who asserted the absence of a link between IT investments and improved productivity using a production function of the Cobb-Douglas form.

Studies recently carried out by several authors have highlighted several factors that have contributed to the "Productivity Paradox". First, and according to Triplett (1997), some IT spillovers, especially in the service sector, have not been captured in productivity statistics. Second, the implications of using IT could take a considerable amount of time to materialize. Finally, and to measure the impact of IT on the performance of firms, several earlier studies relied on relatively small samples of firms. This could lead to less robust and statistically less significant results. As a result, many studies conducted on this question notably those of Brynjolfsson and Hitt (1996), Oliner and Sichel (2000) have qualified Solow's assertion. Brynjolfsson (2001) has shown, from the estimation of a Cobb-Douglas production function of a sample of 367 firms over the period 1987-1991, that IT investments give firms higher productivity than other types of investment. 
Several explanations have been put forward to explain the poor efficiency of IT in improving the performance of banks. Firstly, some researchers have identified errors in performance measurement with traditional tools proving to be ineffective in determining precisely the costs and performance associated with computerization. The problems encountered are at the level of inputs than outputs (Thenet \& Guillouzo, 2002). Also, Entorf et al. (1999) add that the impact perimeter of an IT investment is difficult to define especially in the banking sector with the organization of network branches and the establishment of EDI (electronic data exchange) links with client companies. Secondly, the existence of problems in defining general concepts such as IT and bank performance is therefore in measuring the impact of the former on the latter. The notion of IT is indeed difficult to define: it is not limited to materials and equipment, but also includes intangible investments. On the other hand, some studies on the "Productivity Paradox" have found a positive relationship between investment in IT and firm performance. Industry-level research has yielded several results. This is partly because IT is indirectly linked to the performance of the firm (Chen \& Zhu, 2004). Indeed, according to these authors, the link between IT investment and firm performance is indirect because of the mediating and moderating variables.

While most of the work on the effects of IT investments has focused on evaluating productivity, very few economists have tried to study the effects of these investments on the evolution of firm profitability.

\section{IT Investments and Profitability}

The profit function offers the advantage of measuring performance through output but also input. It is made up of the "income" variable resulting from specialization or diversification and the "costs" one resulting from the combination of a certain number of inputs. Controlling a company's performance requires mastering managerial practices, but measuring them is a real challenge. Also, manufacturing performance appears to be much easier to measure than that of services (Akber, 2019). Unlike the traditional economy which often associates the production and consumption of commodities with the quantities of output which were considered to be performance indicators, the modern economy is characterized by a diversity of products and services (Singh \& Singh Brar, 2016). In this environment, the traditional tools of productivity are no longer appropriate.

In the case of the banking industry or financial institutions defining performance reverts to measure certain indicators such as ROA (Return on Assets) which is an instrument used by many authors such as Barua et al. (1991). They found a positive correlation between investment in IT and bank performance as measured by ROA and ROE (Return on Equity) which assesses the efficiency of firms by the use of their financial capital. This tool has been used in many studies. While Alpar and Kim (1990) found that by measuring the impact of IT investments on the performance of manufacturing firms reasoning on the value generated by IT can mislead, Prasad and Harker (1997) and Brynjolfsson and Hitt (1996) have shown the existence of a negative correlation between IT investments and firms' ROE. However, Bakos (1993) showed the ambiguity of the relationship between these two variables. In addition to the ROA and ROE, some authors have considered the Total Shareholder Return which makes it possible to calculate the value created by the firm for the shareholders. This tool was introduced by Dos Santos and al. in 1993. These authors have shown the existence of a positive correlation between investment in IT and the performance of firms measured by the Total Shareholder Return. Finally, Gayathri and Suvitha (2018) tried to measure the impact of IT on the profitability of 21 Indian banks (12 
public and 9 private banks) over the period 2011-2015. Their results show that IT investments have a positive impact on the profitability and performance of banks more than marketing expenses, knowing that profitability was measured by profit after tax (PAT). They concluded that Indian banks should promote technology in their operations.

To sum up, we can say that the results of studies on the impact of IT on the profitability of banking firms are often contradictory. The various studies on the effects of IT investments on the profitability of user firms often show that these investments have no impact on the profitability of banking firms. However, several authors claim the opposite, that is, the existence of a positive association between these two variables.

\section{METHOD}

For this research, we considered a database made up of variables whose choice was guided by recent studies on bank performance.

\section{Research Hypothesis}

The literature review exposed above enabled us to identify a set of variables supposed to explain variations in performance levels among banks. We have selected those which seem to better characterize the Tunisian banking system and whose data are available throughout the study period (2001-2019). Each of these variables is translated by a separate assumption.

Hypothesis 1: Effect of information technology

Works studying the effects of IT investments on the profitability of the user companies often show that these investments have no impact on the profitability of banking firms. Most of these studies have concluded that there is no link between these two variables, notably the work of Licht and Moch (1999), Gayathri and Suvitha (2018). In our study, a positive sign of this variable is expected since IT has the potential to reduce operating costs. We then state our first hypothesis:

\section{$H_{1}$ : Investment in IT has a positive impact on bank profitability.}

Hypothesis 2: Effect of the "intermediation" variable

The "intermediation" variable will be measured by the "interest margin/GNP" ratio. A low ratio could lead to increased profitability of banks to the extent that they benefit from economies of scale. In this context, Ben Naceur (2003) adds that the lower this ratio, the higher the interest and profit margins. We then state our second hypothesis:

$\mathrm{H}_{2}$ : The "intermediation" variable has a positive effect on profitability.

Hypothesis 3: Effect of size

Cook and al. (2000) emphasized that large banks, generally publicly owned, operate on a suboptimal scale and tend to grant loans regardless of their profitability to promote primarily political priorities. They thus find themselves with a large volume of irrecoverable credits. We can therefore expect a negative effect of size on banking performance.

$H_{3}$ : The size variable has a negative effect on bank profitability. 
Hypothesis 4: Effect of credit risk

According to Yao (2005), the issue of banking risk is one of the recurring actual themes. According to Kupper (1998), financial institutions face three main types of risk: credit risk, market risk, and operational risk. According to the Basel Committee (2007), the most important banking risk is credit risk. The latter is generally measured by the weight of provisions in the result of gross receivables. Indeed, the rise in risks can be explained by the allocations to provisions made by banks. This increase in provisions affects banks' results. We thus conclude the higher this risk, the greater the probability of having bad debts, and therefore lower bank profitability.

\section{$H_{4}:$ The risk variable has a negative effect on bank profitability.}

Hypothesis 5: Effect of the staff supervision rate

According to Zaghla and Boujelbene (2008), the more the bank employs high-quality staff the more, it manages to control its use of inputs and therefore maximizes its output level. This idea is retrieved from the work carried out on the banking industry by Chaffai (1997) who have shown that productivity gains expected from an improvement in managerial efficiency are more significant than those achieved by size effect. Therefore, the "staff supervision rate" ratio positively influences the profitability of banks since it leads to an improvement in agents' productivity.

$H_{5}:$ The variable "staff supervision rate" has a positive effect on profitability.

Hypothesis 6: Bank public ownership versus private ownership

Several studies have shown that a bank's capital ownership can be an important variable in explaining bank profitability. According to Bourke (1989), there is a negative relationship between the public ownership of a bank and its profitability. This is explained by the fact that the objective of public banks is not always profit maximization but rather the financing of strategic sectors with a relatively high-level risk. However, Molyneux and Thornton (1992) found that there is a positive relationship between bank public ownership and return on equity. State-owned banks generate a higher return on equity than their private sector counterparts as the government implicitly covers the transactions carried out by the latter by the fact that public banks generally maintain a lower capital ratio. We then expose our last hypothesis:

\section{$H_{6}$ : The variable "bank ownership" has a negative effect on profitability.}

\section{Sample Presentation}

To determine the impact of IT investment on bank profitability, we will use a sample of 15 Tunisian banks. The database that we have built for this analysis depends on the availability of data in Tunisia. However, the only publicly available individual banking data are those published in banks' activity reports and by databases of the Tunisian Professional Association of Banks and Financial Institutions (TPABFI), the latter themselves taken from balance sheets and accounts of results published by banks. The data are collected over 19 years from 2001 to 2019, that's to say 285 observations. 


\section{Definition of Variables}

In the model that we will adopt, profitability will be regressed on the use of IT (variable of interest) and other appropriate variables (control variables). Table (1) defines the different variables retained in our study and specifies the expected signs:

Table 1. Definition of variables

\begin{tabular}{|c|c|c|c|}
\hline Variables & Definition & Sources & $\begin{array}{l}\text { Expected } \\
\text { sign }\end{array}$ \\
\hline \multicolumn{4}{|l|}{ The dependent variable } \\
\hline Profitability (P) & $\begin{array}{l}\text { The ROA: Net income/Total assets. It measures the bank's } \\
\text { ability to convert assets into net income and is therefore } \\
\text { interested in the overall value of the bank, in other words, } \\
\text { economic profitability. } \\
\text { The ROE: Net income/Equity. This ratio makes it possible to } \\
\text { assess the performance from the point of view of the } \\
\text { shareholders. } \\
\text { The NIM: (Sum of interest income - Sum of interest expense) } \\
\text { / Total assets. }\end{array}$ & $\begin{array}{l}\text { TPABFI and } \\
\text { ARB }\end{array}$ & \\
\hline \multicolumn{4}{|l|}{ The independent variables } \\
\hline $\begin{array}{l}\text { Variable of interest: } \\
\text { Investments in IT (IT) }\end{array}$ & $\begin{array}{l}\text { Tangible (material), intangible (software), training, and } \\
\text { maintenance investments related to the bank's equity }\end{array}$ & Questionnaire* & + \\
\hline \multicolumn{4}{|l|}{ Control variables: } \\
\hline $\begin{array}{l}\text { Intermediation (INT) } \\
\text { Size (SIZE) } \\
\text { Credit risk (CRISQ) }\end{array}$ & $\begin{array}{l}\text { Interest margin/GNP } \\
\text { Natural logarithm of total assets (in DT) } \\
\text { Litigation rate calculated by overdue debts ratio to total } \\
\text { credits }\end{array}$ & $\begin{array}{l}\text { TPABFI } \\
\text { TPABFI } \\
\text { CBT }\end{array}$ & $\begin{array}{l}+ \\
-\end{array}$ \\
\hline $\begin{array}{l}\text { Staff } \\
\text { (SSR) }\end{array}$ & $\begin{array}{l}\text { Share of senior executives in relation to the total workforce. } \\
\text { Dummy variable (mute) which takes the value } 1 \text { at year } t \text { if the } \\
\text { bank is public, } 0 \text { if the bank is private. }\end{array}$ & TPABFI & $\begin{array}{l}+ \\
-\end{array}$ \\
\hline
\end{tabular}

ARB: Annual reports of banking activities. TPABFI: Tunisian Professional Association of Banks and Financial Institutions. CBT: Central Bank of Tunisia.

* To collect data relating to IT investments from Tunisian banks, we opted for a questionnaire to be sent to Management Control Directors or Information System Directors of these banks. This questionnaire aims to find out the amounts invested in IT during the period 2001-2019.

\section{Econometric Approach and Model Specification}

We will follow a standard form, adopted by Beccalli (2007), to estimate the relationship between IT investment and profitability measurement. Therefore, we decline the IT investment and control variables against the measure of profitability. The model we are going to estimate is as follows: 


$$
P_{i t}=\alpha_{i}+\beta_{1 i t} I T_{i t}+\beta_{2 i t} \operatorname{SIZE}_{i t}+\beta_{3 i t} \operatorname{INT}_{i t}+\beta_{4 i t} \operatorname{SSR}_{i t}+\beta_{5 i t} C_{\text {RISQ }}+\beta_{6 i t} B_{\text {BOWN }}+\varepsilon_{i t}
$$

Where $\mathrm{P}_{\mathrm{it}}$ measures the profitability of bank "i" at date "t" either through the ROA and ROE ratios or through the net interest margin (NIM), $\mathrm{IT}_{\mathrm{it}}$ is the variable "IT investments". Note that in the literature, several ratios have been used to measure IT investments. These ratios refer to different size measures such as the number of staff, equity, total cost, and sales. Based on the convention established in the literature using IT ratios to test the relationship between IT investments and financial performance, in this study we use the IT/Equity ratio (share of IT in banks' equity). The current choice of the denominator for IT measurement will not significantly affect the results (Beccalli, 2007). SIZE $\mathrm{it}_{\mathrm{it}}$ is the "size" variable measured by the logarithm of the active total, $\mathrm{INT}_{\mathrm{it}}$ is the intermediation variable measured by the ratio of interest margin to GNP, CRISQ $_{i t}$ is the "credit risk" variable calculated by the ratio of overdue debts to total loans, SSR $_{\text {it }}$ is the "supervision rate" variable measured by the share of senior managers in relation to the total workforce, $\mathrm{BOWN}_{\mathrm{it}}$ is a dummy variable $=1$ if a bank " $\mathrm{i}$ " at period " $\mathrm{t}$ " is public and $=0$ if a bank "i" at period "t" is private, $\varepsilon_{\mathrm{it}}$ : error term. The estimation of our model will be done using two approaches: the first is static and the second is dynamic.

Model (1) is first estimated using the assumption of uniformity of behavior over time and among banks. We estimate the model using the Ordinary Least Squares (OLS) method by assuming that the error is the same and follows the normal distribution $\mathrm{N}(0, \sigma)$. The specification of the above model implies that the coefficients obtained are identical for the 15 banks considered. However, it is possible to think that there are differences between Tunisian banks in their activity and functioning. It is, therefore, appropriate to adopt a specification that highlights individual effects. This is why we resume the specification (1) again by introducing heterogeneity between the banks. By performing the Fisher test (F-test) and the Breusch and Pagan Lagrangian Multiplier (LM) test, we accept the rejection of a perfectly homogeneous panel structure and therefore our model is either a fixed individual effects model or a random individual effects one. Based on the values of this statistic, we reject the $\mathrm{H}_{0}$ hypothesis (lack of autocorrelation). This implies that the fixed effects model is preferable to the random effects model in the case where we consider the banks' net interest margin as a variable to be explained. The choice then relates to the "Within" estimator.

The same approach was followed to determine the best estimator of the model where performance is measured by the banks' ROE. The results show that the random-effects model is preferable to the fixed effects model according to the Hausman test. However, considering the ROA as an explanatory variable, the estimated results have shown that there are no individual effects specific to each bank. Since the specific deterministic effect symbolized by constant values specific to each bank is not proven, it might seem more natural to treat this effect as a random and non-deterministic effect. The random-effects model to be estimated is written:

$\mathrm{P}_{\mathrm{it}}=\alpha+\beta_{1 \mathrm{it}} \mathrm{IT}_{\mathrm{it}}+\beta_{2 \mathrm{it}} \mathrm{SIZE}_{\mathrm{it}}+\beta_{3 \mathrm{it}} \mathrm{INT}_{\mathrm{it}}+\beta_{4 \mathrm{it}} \mathrm{SSR}_{\mathrm{it}}+\beta_{5 \mathrm{it}} \mathrm{CRISQ}_{\mathrm{it}}+\beta_{6 \mathrm{it}} \mathrm{BOWN}_{\mathrm{it}}+\varepsilon_{\mathrm{it}}$

$\varepsilon_{\mathrm{it}}=\mu_{\mathrm{i}}+\rho_{\mathrm{it}}$

To introduce the specific effect as a random effect into the analysis, we consider that the error, or residue $\varepsilon_{i t}$, is composed of two elements: the first represents the individual effect, reflecting the influence on the performance of variables not taken into account, as long as they are stable over time; the second represents the influence of the other omitted variables also 
varying over time from one bank to another. We assume that the $\varepsilon_{i t}$ are identically and independently distributed and that the $\mu_{\mathrm{i}}$ are not correlated with the explanatory variables. The estimated model for performance equations is usually written in the following form:

$$
\mathrm{P}_{\mathrm{it}}=\beta \mathrm{IT}_{\mathrm{it}}+\delta \mathrm{X}_{\mathrm{t}}^{\mathrm{k}}++\mu_{\mathrm{i}}+\rho_{\mathrm{it}}
$$

In this specification, the variable $\mathrm{P}_{\text {it }}$ represents the performance variable of bank $\mathrm{i}$ at time $\mathrm{t}$, such as NIM, ROA, and ROE. X corresponds to a vector composed of (k) control variables; $\mu_{\mathrm{i}}$ represents the specific effect specific to each bank, which remains invariable over time, while $\rho_{\text {it }}$ is a random perturbation. The index (i) refers to the banks in our sample and " $t$ " is the time index. The estimation of this model will be done according to a static approach and a dynamic approach. In our study, the partial adjustment approach is applied to our equation.

Model (3) was estimated on panel data according to two methodologies that take into account the characteristics of our sample. Initially, the estimation is carried out by the OLS method. Secondly, the announced model is estimated with delays of the endogenous variable. Thus, the estimated dynamic equations take the following form:

$$
\mathrm{P}_{\mathrm{it}}=\Sigma \varphi_{\mathrm{m}} \mathrm{P}_{\mathrm{i}, \mathrm{t}-1}+\beta \mathrm{IT}_{\mathrm{it}}+\delta \mathrm{X}_{\mathrm{t}}^{\mathrm{k}}+\mu_{\mathrm{i}}+\rho_{\mathrm{it}}
$$

The vector of control variables $\mathrm{X}_{\mathrm{t}}^{\mathrm{k}}$ has the same meaning as before. The variable $\mathrm{P}_{\mathrm{i}, \mathrm{t}-1}$ is the delayed endogenous variable. We also assume that the absolute value of the sum of parameters $\varphi_{\mathrm{m}}$ is less than unity and that $\rho_{\mathrm{it}}$ is the error term with zero expectation and variance $\mathrm{E}$ $\left(\rho_{\mathrm{it}}{ }^{2}\right)=\sigma_{\rho}{ }^{2}$. Moreover, these stochastic disturbances are independent of the specific effects $\left(\mu_{\mathrm{i}}\right)$ and taken in pairs; they are not correlated. On the other hand, the presence of a lagged variable makes the usual estimation techniques on panel data inappropriate. This is due to the correlation between the endogenous variable and residuals from the regression. To overcome this problem, the method of instrumental variables applied to the first difference model allows endogeneity to be taken into account by the use of delayed explanatory variables as instruments.

Arellano and Bond (1991) proposed a procedure of estimations by the Generalized Moments' Method (GMM) to improve the efficiency of the method proposed by Anderson and Hsiao (1981-1982) and which proved to produce consistent estimators that are not necessarily effective. This procedure contains two steps. First of all, it is necessary to rewrite the dynamic model in first differences to eliminate the specific effects $\left(\mu_{\mathrm{i}}\right)$, and in a second step, this equation is estimated according to the GMM method by adopting a set of instrumental variables. The vector of instrumental variables retained in this analysis is composed of all the delayed values of the endogenous variable.

\section{RESULTS AND DISCUSSION}

Table (2) shows the disparity in the mean values of the explanatory variables, the variables to be explained, and their standard deviations for the different banks in the sample.

Table 2. Descriptive statistics of the variables to be explained and the explanatory variables

\begin{tabular}{|l|l|l|l|l|}
\hline & Average & $\begin{array}{l}\text { Standard } \\
\text { deviation }\end{array}$ & Min & Max \\
\hline NIM & .0256356 & .0174386 & .0075367 & .0763757 \\
\hline ROA & .1174876 & 6.83454 & -74.0456 & 9.26575 \\
\hline
\end{tabular}




\begin{tabular}{|l|l|l|l|l|}
\hline ROE & 7.834567 & 80.5646 & -428.4564 & 954.3454 \\
\hline IT & .0114998 & .087343 & -1.116654 & .266536 \\
\hline INT & .652881 & .136754 & .2154757 & .9583346 \\
\hline SIZE & 13.64798 & 1.28343 & 10.5267 & 15.28674 \\
\hline SSR & .2147646 & .0856464 & 0 & .4364674 \\
\hline RISQ & .1486752 & .1176954 & .02 & .565 \\
\hline
\end{tabular}

Looking at Table (3), we see that the average net interest margin of Tunisian banks decreases slightly from 0.0364 in 2001 to 0.0357 in 2019 . On the other hand, the average ROA increased by 0.024 in 2001 to reach 3.758 in 2019. The same goes for the ROE which goes on average from 0.157 in 2001 to 12.748 in 2019. The average numbers of IT investments clearly show that our sample is based on banks installed in a growing country in terms of technology. To get around the multicollinearity problem, we were able to select only the best variables (Table 4).

Table 3. Annual descriptive statistics of performance measures and IT investment in Tunisian banks

\begin{tabular}{|c|c|c|c|c|c|c|c|}
\hline NIM & 2001 & 2004 & 2007 & 2010 & 2013 & 2016 & 2019 \\
\hline Average & .036475 & .0336467 & .0306613 & .0267485 & .0264566 & .0249437 & .0357654 \\
\hline $\begin{array}{l}\text { Deviation } \\
\text { standard }\end{array}$ & .008175 & .0105987 & .013549 & .0098103 & .0094424 & .0070653 & .0072169 \\
\hline Min & .0149432 & .0196912 & .0113846 & .0124497 & .0076826 & .0114803 & .0090055 \\
\hline Max & .0673452 & .0522107 & .0638269 & .0428411 & .0397337 & .035338 & .1564324 \\
\hline ROA & 2001 & 2004 & 2007 & 2010 & 2013 & 2016 & 2019 \\
\hline Average & .024563 & .820709 & $\begin{array}{l} \\
7.839602\end{array}$ & .8706546 & .411611 & 1.191564 & 3.75832 \\
\hline $\begin{array}{l}\text { Deviation } \\
\text { standard }\end{array}$ & .0095347 & 1.179944 & 21.01162 & 1.346316 & 2.591446 & 1.084216 & .8212117 \\
\hline Min & .0054411 & .6155183 & $\begin{array}{l}- \\
75.19608\end{array}$ & -1.711013 & 8.130311 & 0 & .0414251 \\
\hline Max & .1435653 & 5.016689 & 1.977789 & 4.086188 & 3.931209 & 3.608938 & 5.970182 \\
\hline ROE & 2001 & 2004 & 2007 & 2010 & 2013 & 2016 & 2019 \\
\hline Average & .1574643 & 0.68589 & $\begin{array}{l} \\
29.29276 \\
\end{array}$ & 4.490838 & $-\overline{6.716453}$ & 8.801352 & 12.74893 \\
\hline $\begin{array}{l}\text { Deviation } \\
\text { standard }\end{array}$ & .0614159 & 9.350515 & 111.8833 & 5.113827 & 47.21951 & 7.761342 & 5.522733 \\
\hline Min & .0117211 & 1.167886 & $\begin{array}{l} \\
429.0495\end{array}$ & -4.225255 & $\begin{array}{l}- \\
176.4798\end{array}$ & 0 & .2059946 \\
\hline Max & .2032746 & 39.89513 & 13.0334 & 14.55628 & 15.07121 & 29.76911 & 29.44269 \\
\hline IT & 2001 & 2004 & 2007 & 2010 & 2013 & 2016 & 2019 \\
\hline Average & .026578 & 0152642 & .0143741 & .0149916 & .0282695 & .0334631 & .468532 \\
\hline $\begin{array}{l}\text { Deviation } \\
\text { standard }\end{array}$ & .0204895 & .0214314 & .0231528 & .023959 & .0529575 & .0784827 & .0779477 \\
\hline
\end{tabular}




\begin{tabular}{|l|l|l|l|l|l|l|l|}
\hline Min & .0001479 & .000317 & .0004975 & .0002913 & .0009346 & .0014959 & .0016363 \\
\hline $\operatorname{Max}$ & .0748671 & .0834234 & .0907636 & .09402151 & .1974172 & .3046716 & .4953611 \\
\hline
\end{tabular}

Table 4. Matrix of the variables' correlations

\begin{tabular}{|l|l|l|l|l|l|l|l|l|}
\hline Variables & NIM & ROA & ROE & INT & SIZE & SSR & CRISQ & IT \\
\hline NIM & 1.0000 & & & & & & & \\
\hline ROA & -0.0576 & 1.0000 & & & & & & \\
\hline ROE & -0.0734 & 0.3267 & 1.0000 & & & & & \\
\hline INT & 0.6816 & -0.046 & -0.1156 & 1.0000 & & & & \\
\hline SIZE & -0.6728 & 0.1574 & 0.1465 & -0.4564 & 1.0000 & & & \\
\hline SSR & 0.1276 & -0.0564 & -0.0463 & 0.0054 & -0.1267 & 1.000 & & \\
\hline CRISQ & -0.4536 & 0.0264 & 0.2546 & -0.2675 & 0.2564 & -0.1683 & 1.000 & \\
\hline IT & -0.0356 & 0.1258 & -0.021 & -0.0265 & 0.0564 & -0.0536 & 0.0375 & 1.000 \\
\hline
\end{tabular}

We present here the empirical results concerning the determinants of bank profitability as measured by the three indicators explained above namely the NIM, the ROE, and the ROA. Interpretations of the obtained results will allow us to clarify the sign and extent of the estimated relationships.

\section{The Sensitivity of the Net Interest Margin to IT Investment}

To determine the impact of IT investment on the NIM of Tunisian banks, we estimated the previous dynamic and static specifications where the endogenous variable to be explained is the ratio of the bank interest margin to the total assets of each bank. The results of the estimations are displayed in the table (5).

Table 5. Results of the estimation of the net interest margin equation

\begin{tabular}{|c|c|c|c|c|}
\hline \multirow[b]{2}{*}{ Variables } & \multirow{2}{*}{$\begin{array}{l}\text { Model 1: } \\
\text { Fixed effects } \\
\text { Coefficient } \\
\text { (Student's t) } \\
\end{array}$} & \multicolumn{2}{|c|}{ Model 2: Random effects } & \multirow{2}{*}{$\begin{array}{l}\text { Dynamic panel } \\
\text { Coefficient } \\
\text { (Student's t) }\end{array}$} \\
\hline & & $\begin{array}{l}\text { Coefficient } \\
\text { (Student's t) }\end{array}$ & $\begin{array}{l}\text { Coefficient } \\
\text { (Student's t) }\end{array}$ & \\
\hline NIM (-1) & - & - & - & $\begin{array}{l}0,0163 \\
(0,83)\end{array}$ \\
\hline IT & $\begin{array}{l}0,0045 \\
(0,34)\end{array}$ & $\begin{array}{l}0,121 \\
(6,54)\end{array}$ & $\begin{array}{l}0,0091 \\
(0,54)\end{array}$ & $\begin{array}{l}0,0018^{* * * *} \\
(5,41)\end{array}$ \\
\hline INT & $\begin{array}{l}0,0347 * * * \\
(4,23)\end{array}$ & $\begin{array}{l}0,035^{* * * *} \\
(6,21)\end{array}$ & $\begin{array}{l}0,017 * * * \\
(6,43)\end{array}$ & $\begin{array}{l}0,3711 * * * \\
(6,37)\end{array}$ \\
\hline SIZE & $\begin{array}{l}-0,0242 * * * \\
(-8,14)\end{array}$ & $\begin{array}{l}-0,0095 * * * \\
(-5,61)\end{array}$ & $\begin{array}{l}-0,0082 * * * \\
(-4,23)\end{array}$ & $\begin{array}{l}-0,0281 * * * \\
(-10,62)\end{array}$ \\
\hline SSR & $\begin{array}{l}0,025^{* * * *} \\
(3,76)\end{array}$ & $\begin{array}{l}0,0081 \\
(0,83)\end{array}$ & $\begin{array}{l}0,0275 \\
(1,83)\end{array}$ & $\begin{array}{l}0,0037 * * \\
(2,82)\end{array}$ \\
\hline CRISQ & $\begin{array}{l}-0,0165 * * \\
(-2,78)\end{array}$ & $\begin{array}{l}0,0039 \\
(0,76)\end{array}$ & $\begin{array}{l}-0,0361 \\
(-1,62)\end{array}$ & $\begin{array}{l}-0,5130 * * \\
(-2,46)\end{array}$ \\
\hline
\end{tabular}




\begin{tabular}{|l|l|l|l|l|}
\hline Constant & $0,237 * * *$ & $0,182 * * *$ & $0,085 * * *$ & $0,282 *$ \\
& $(8,58)$ & $(5,73)$ & $(5,12)$ & $(11,41)$ \\
BOWN & - & - & $\begin{array}{l}0,026 * * \\
(2,62)\end{array}$ & - \\
\hline $\mathbf{R}^{2}$ & $64,75 \%$ & $45,82 \%$ & $43,78 \%$ & \\
\hline
\end{tabular}

*** Significant at the $1 \%$ threshold, ** Significant at the 5\% threshold, * Significant at the $10 \%$ threshold.

Fisher's test indicates that the model is globally significant up to the $1 \%$ threshold (Prob> $\mathrm{F}=0.0000$ ). The goodness of adjustment is acceptable since the model explains $64.75 \%$ of the total variance. The results show some similarities. The two static models, fixed effects and random effects show that IT investments have no impact on the NIM of the banks in the sample. This result confirms that found by Prasad and Harker (1997) who concluded in their work that there is no link between these two variables. The third model is based on the assumption that all the explanatory variables are exogenous as in the static case. The delayed profitability variable (in first differences) is instrumented by its own delays at level $\mathrm{t}-3$. For the sake of comparison, estimates by the GMM method suggested by Arellano and Bond (1991) applied to the dynamic performance equation are also included in Table (5). Although the lagged coefficient is not significant, it appears that IT has a positive and significant relationship at the $1 \%$ level with the NIM of banks.

Importantly, the size and intermediation parameters remain statistically significant at the $1 \%$ level in all estimates, whether dynamic or static. This result thus observed suggests that these two variables, combined with IT, influence the NIM of Tunisian banks. However, this significant influence is positive for the "intermediation" variable but negative for the "size" variable. It, therefore, appears that the intermediation activity, combined and accentuated by the development and use of new technologies, plays an important role for Tunisian banks since it improves their NIMs. This result can be explained by the complementarity between bank credit and deposit policies and the use of IT. Indeed, the strengthening of the credit policy should be carried out in symbiosis with an efficient strategy of draining additional resources and with efficient use of IT. This will undoubtedly lead to an increase in the interest margin of the banks. On the other hand, and concerning the significant but negative relationship between the size variable and the NIM, it appears that the larger the size of the banks the more their interest margin deteriorates. This result confirms that found by Hermalin and Wallace (1994), Isik and Hassan (2002), Bakkeri and Ali (2020) who found a negative relationship between the size and the profitability of banks. On the other hand, this result contradicts the conclusions of Aly and al. (1990), Berger and al. (1993) who argue that the larger the size, the more banks have a positive attitude towards the development of new technologies, and therefore the more their performance improves. The simplest explanation is the existence of substitution between IT and labor to produce more and at a lower cost.

According to the results of the static panel with fixed effects, the managerial capacity of staff is significantly and positively linked to the NIM of Tunisian banks at the $1 \%$ threshold. This result is similar to that found by the dynamic panel with a positive significance at the $5 \%$ level. It, therefore, appears that a high staffing rate and good training of executives lead to an improvement in the productivity of agents and a significant managerial capacity, which has a positive influence on the MIN of banks. This result confirms that found by Zaghla and Boujelbene (2008) who showed that an increase in the supervisory rate positively affects the level of profitability of Tunisian banks and that the latter therefore do not suffer from weak 
managerial capacity. Ben Naceur (2003) insisted on the major positive impact of managerial variables since they positively affect interest margins.

As for the "risk" variable measured by the ratio of overdue debts to total bank credit, the estimation of the model by the static panel with fixed effects and by the dynamic panel reveals that this variable significantly and negatively affects the NIM of Tunisian banks at the 5\% threshold. The policy of compliance with international standards in terms of prevention against insolvency risk encouraged Tunisian banks to increase their capital volumes, which deteriorated the volume of loans granted to individuals and therefore the interest margin received.

Finally, concerning the dummy variable, the results of the static random-effects model show a positive and significant sign at the 5\% level. This result suggests that public banks are more profitable than private banks when considering their NIMs. This confirms the results previously found by Chaffai and Dietsch (1998), Smida and Ayadi (2006), Anwar and al. (2020).

\section{The Sensitivity of Profitability Measures to IT Investment}

Econometric tests show that our model is globally significant and that the quality of adjustment is practically good. This means that there are other variables, in particular economic zones, which would explain performance apart from financial, environmental, or managerial factors. Table (6) shows that according to the model estimations by the dynamic panel method, the ROE is negatively affected by the IT investments of banks. This relationship is significant at the $1 \%$ level. This finding argues that large IT investments are not associated with high returns. This confirms the "Productivity Paradox" and implies that Tunisian banks which devote large budgets to IT investment do not improve their ROE. In contrast, the random-effects model presents a contradictory result: investment in IT is significantly and positively linked to the ROE of banks at the $1 \%$ threshold. The results also show that the relationship between IT investment and banks' ROA is less clear. The random-effects model showed no link between these two variables. On the other hand, according to the results of the dynamic panel, with a significant lagged coefficient at the $1 \%$ threshold, it appears that IT has a positive relationship with the ROA of banks.

Table 6. Results of the estimation of the equation on ROE and ROA

\begin{tabular}{|c|c|c|c|c|c|c|c|}
\hline \multirow[b]{2}{*}{ Variables } & \multicolumn{2}{|c|}{ Model 2: Random effects } & \multirow{2}{*}{$\begin{array}{l}\text { Dynamic } \\
\text { panel }\end{array}$} & \multirow[b]{2}{*}{ Variables } & \multicolumn{2}{|c|}{ Model 2: Random effects } & \multirow{2}{*}{$\begin{array}{l}\text { Dynamic } \\
\text { panel }\end{array}$} \\
\hline & $\begin{array}{l}\text { Coefficient } \\
\text { (Student's t) }\end{array}$ & $\begin{array}{l}\text { Coefficient } \\
\text { (Student's t) }\end{array}$ & & & $\begin{array}{l}\text { Coefficient } \\
\text { (Student's t) }\end{array}$ & $\begin{array}{l}\text { Coefficient } \\
\text { (Student's t) }\end{array}$ & \\
\hline ROE (-1) & - & - & $\begin{array}{l}0,022 * * * \\
(2,54)\end{array}$ & ROA (-1) & - & - & $\begin{array}{l}0,074 * * * \\
(4,76)\end{array}$ \\
\hline IT & $\begin{array}{l}-645,13 * * * \\
(-32,45)\end{array}$ & $\begin{array}{l}1,625^{* * * *} \\
(0,08)\end{array}$ & $\begin{array}{l}-735,69 * * * \\
(-5,43)\end{array}$ & IT & $\begin{array}{l}7,143 \\
(1,67)\end{array}$ & $\begin{array}{l}8,174 \\
(6,336)\end{array}$ & $\begin{array}{l}4,732 * * * \\
(32,78)\end{array}$ \\
\hline INT & $\begin{array}{l}-24,75 \\
(-0,65)\end{array}$ & $\begin{array}{l}-32,11 \\
(-0,68)\end{array}$ & $\begin{array}{l}55,712 * \\
(1,68)\end{array}$ & INT & $\begin{array}{l}0,013 \\
(0,04)\end{array}$ & $\begin{array}{l}0723 \\
(4,08)\end{array}$ & $\begin{array}{l}18,62 * * * \\
(18,72)\end{array}$ \\
\hline SIZE & $\begin{array}{l}6,82 \\
(1,37)\end{array}$ & $\begin{array}{l}6,128 \\
(0,71)\end{array}$ & $\begin{array}{l}79,412 * * * \\
(7,59)\end{array}$ & SIZE & $\begin{array}{l}0,746^{* * *} \\
(1,72)\end{array}$ & $\begin{array}{l}1,518^{* *} \\
(0,903)\end{array}$ & $\begin{array}{l}9,75 * * * \\
(2,82)\end{array}$ \\
\hline SSR & $\begin{array}{l}-13,82 \\
(-0,88)\end{array}$ & $\begin{array}{l}-7,295 \\
(-0,42)\end{array}$ & $\begin{array}{l}-54,933^{*} \\
(-1,75)\end{array}$ & SSR & $\begin{array}{l}-1,471 \\
(-0,08)\end{array}$ & $\begin{array}{l}-8,621 \\
(9,68)\end{array}$ & $\begin{array}{l}0,114 \\
(0,03)\end{array}$ \\
\hline CRISQ & $\begin{array}{l}121,45^{* *} \\
(1,72)\end{array}$ & $\begin{array}{l}120,53 * * \\
(1,64)\end{array}$ & $\begin{array}{l}-21,907 \\
(-0,61)\end{array}$ & CRISQ & $\begin{array}{l}-2,114 \\
(-0,83)\end{array}$ & $\begin{array}{l}-0,735 \\
(6,993)\end{array}$ & $\begin{array}{l}-3,896 \\
(-0,64)\end{array}$ \\
\hline
\end{tabular}




\begin{tabular}{|c|c|c|c|c|c|c|c|}
\hline $\begin{array}{l}\text { Constant } \\
\text { BOWN }\end{array}$ & $\begin{array}{l}-76,34 \\
(-1,36) \\
-\end{array}$ & $\begin{array}{l}-76,13 \\
(-0,87) \\
1,341 \\
(0,09) \\
\end{array}$ & $\begin{array}{l}-45,247 * * * \\
(-7,82) \\
-\end{array}$ & $\begin{array}{l}\text { Constant } \\
\text { BOWN }\end{array}$ & $\begin{array}{l}-11,97 \\
(-1,51) \\
-\end{array}$ & $\begin{array}{l}-25,72 * * \\
(11,95) \\
5,735 \\
(2,00)\end{array}$ & $\begin{array}{l}- \\
86,45 * * * \\
(-7,72) \\
-\end{array}$ \\
\hline $\mathbf{R}^{2}$ & $47,18 \%$ & $38,62 \%$ & & $\mathbf{R}^{2}$ & $37,93 \%$ & $39,44 \%$ & \\
\hline
\end{tabular}

*** Significant at the $1 \%$ threshold, ** Significant at the 5\% threshold, * Significant at the $10 \%$ threshold.

The lack of a clear relationship between IT investment and measures of bank profitability is consistent in early work by Brynjolfsson and Hitt (1996). These authors have found different reasons for this result. They referred to the ability of IT to reduce or increase barriers to entry, and therefore to intensify or decrease competition. They also cited, as another reason, the effect of IT on competitive strategy and the structure of the industry. Also, the work of Omri and Hachana (2008) provides a better explanation for this ambiguity in the relationship between IT investment and measures of bank profitability. These authors have confirmed in their work one of the explanations of the "Productivity Paradox" which is the existence of delay. Indeed, they raised, on the one hand, that taking into account the delay between investment in IT and financial measures of profitability slightly improves the relationship between these two variables, and that efficiency-X explains better than traditional ratios the relationship between IT investment and bank profitability on the other hand.

The results of the dynamic model show that the "intermediation" variable is favorable to the profitability of banks. This variable is positively and significantly linked to ROE and ROA at the respective thresholds of $10 \%$ and $1 \%$. It, therefore, appears that this managerial variable constitutes an important source of profits for Tunisian banks. This result seems to indicate that the most active banks in the customer lending segment tend to perform better by increasing their ROA and ROE.

As for the "size" variable, empirical results indicate that there is a positive and significant relationship between the size of the bank and the return on assets and equity. Indeed, according to the results of the dynamic panel, size is positively and significantly related to ROE at the $1 \%$ threshold. The relationship between the same explanatory variable and the ROA of Tunisian banks is positive and significant at the 5\% threshold according to the random-effects model, and at the $1 \%$ threshold according to the results of the dynamic panel. These results suggest that the tendency to improve the level of economies of scale generates products and tends to improve profits. These econometric results show that Tunisian banks, with efficient use of IT, have the managerial capacity necessary to manage a large total of assets.

According to the results of the dynamic panel, it is surprising to find that the managerial capacity of staff is significantly but negatively linked to the return on equity of Tunisian banks. The random-effects model shows that there is no positive relationship between this managerial variable and the ROA of Tunisian banks. This result suggests that the executive supervision rate is not high enough to improve and positively influence the profitability measures of banks. It appears that Tunisian banks suffer from low managerial capacity given the low added value of senior executives.

As for the "risk" variable, the estimation of the model reveals that this variable does not affect the ROA of Tunisian banks. However, the influence of non-performing loans on the ROE of these banks is positive and significant at the 5\% threshold according to the results of the random-effects model. This result, although it is different from what is expected, corroborates the results found by Ndeffo and Ningaye (2007) in their study analyzing the impact of the financial reforms implemented in the CEMAC zone since the end of the 1980s on the 
profitability of the banking system of the countries of this sub-region. It, therefore, appears that the more the banks take the risk by granting more loans, the more profitable they are by increasing their ROA. Therefore, banks should extend credit to businesses more to address the excess liquidity problem that has characterized them for several years.

Finally, concerning the dummy variable, the results of the estimated models show that the ownership of the bank, whether public or private, does not affect the profitability measured by the ROA and ROE.

\section{CONCLUSION}

As part of this research, we examined the relationship between IT investment and the profitability of Tunisian banks, via static and dynamic panel regression models. Our study focused on 15 Tunisian banks for 19 years (2001-2019). To assess the profitability of these banks, three measures were used: traditional accounting ratios, ROA and ROE, and net interest margin. Our research has shown the importance of the role played by IT in Tunisian banks since IT investments improve their profitability. This finding contradicts the "Productivity Paradox" that high IT investments are not associated with better performance. Indeed, an analysis of the empirical results of our study shows that IT has a high share of the explanation of bank profitability in comparison with other variables. The dynamic panel estimations suggest that IT favors bank profitability as measured by ROA and NIM, while it is against profitability measured by ROE. It appears that large investments in IT are associated with high returns as measured by the bank's ROA and NIM. We confirm then that Tunisian banks have an interest in investing more in IT and promoting technology in their operations.

The results also show that Tunisian banks are acting on their size to boost their performance, which explains the continuous expansion of the networks of Tunisian banks, and which confirms that the latter have not yet reached a level of the size that will be harmful to their profitability, even if a negative correlation between the size variable and profitability measured by the NIM is detected during our study. It appears that the large Tunisian banks do not follow the concept of economy of scale. Also, the managerial variable "intermediation" is favorable to the profitability of banks measured by the ROA, ROE, and NIM. It is thus an important source of profits for Tunisian banks. The most active banks in the customer loan segment tend to be more efficient by increasing their profitability. The results also showed that Tunisian banks suffer from low managerial capacity given the low added value of senior executives and that the more the banks take the risk by granting more loans, the more profitable they are by increasing their ROA. Therefore, banks should extend credit to businesses more to address the excess liquidity problem that has characterized them for several years. Finally, the results of the estimated models show that the ownership of the bank, whether public or private, does not affect profitability measured by ROA and ROE, but that public banks are more profitable than private banks when considering their NIM.

\section{REFERENCES}

Akber, S. M. (2019). Influential Factors Responsible for Profitability: A Technical Study on Commercial Banks in Bangladesh. International Journal of Accounting \& Finance Review, 4(2), 22-28.

Alpar, P., \& Kim, M. (1990). A microeconomic approach to the measurement of information technology value. Journal of Management, Information Systems, 2(7), 55-69. 
Aly, H., Grabowsky, R., Pasurka, C., \& Rangan, N. (1990).Technical, Scale and Allocative Efficiencies in U.S. Banking: An Empirical Investigation. The Review of Economics and Statistics, 72, 211-218.

Anderson, T.W., \& Hsiao, C. (1981). Estimation of Dynamic Models with Error Components. Journal of American Association, 67(375), 598-606.

Anderson, T.W., \& Hsiao, C. (1982). Formulation and Estimation of Dynamic Models Using Panel Data. Journal of Econometrics, 18, 47-82.

Anwar, J., Seth, H., Vaish, A. K., \& Rao, N. V. M. (2020). Revisiting the Efficiency of Indian Banking Sector: An Analysis of Comparative Models Through Data Envelopment Analysis. Indian Journal of Finance and Banking, 4(1), 92-108.

Arellano, M., \& Bond, S. (1991). Some tests of specification for panel data: Monte Carlo evidence and an application to employment equations. The Review of Economic Studies, 58(2), 277-297.

Bakkeri, A., \& Ali, A. B. (2020). Profitability of Islamic Banks: A Panel Data Analysis. Indian Journal of Finance and Banking, 4(3), 26-38.

Bakos, Y. (1993). IT, incentives and the optima number of suppliers. Journal of Management, Information Systems, 10, 37-53.

Barua, A., Kriebel, C., \& Mukhopadhyay, T. (1991). Information technologies and business value: An analytic and empirical investigation. Information Systems Research, 6(1).

Beccalli, E. (2007). Does IT investments improve bank performance? Evidence from Europe. Journal of Banking and Finance, 31, 2205-2230.

Ben Naceur, S. (2003).The determinants of the Tunisian banking industry profitability: Panel evidence 1980-2000”. Economic Research Forum.

Berger, A. N., Hancock, D., \& Humphrey, D. B. (1993). Bank efficiency derived from the profit function. Journal of Banking and Finance, 17, 317-347.

Berndt, E. (1991).The practice of econometrics: classic and contemporary. Addison Wesley: Reading, MA.

Bourke, P. (1989). Concentration and other determinants of bank profitability in Europe, North America and Australia. Journal of Banking and Finance, 13(1), 65-79.

Brynjolfsson, E. (2001). High-technology industries and market structure: Commentary. Federal Reserve Bank of Kansas City, 103-110. 
Brynjolfsson, E., \& Hitt, L. (1996). Paradox lost? Firm-level evidence of high returns transformation systems spending. Management Science, 42(4), 541-558.

Chaffai, M. E. (1997). Estimation of efficiency frontiers: An overview of recent developments in the literature. Development Economics Review, 3, 33-67.

Chaffai, M. E., \& Dietsch, M. (1998). How to increase the performance of Tunisian commercial banks: A question of organizational or size?. Finance and Development in Maghreb, 24, 79-89.

Chen, Y., \& Zhu, J. (2004). Measuring Information Technology's indirect impact on firm performance. Information Technology and Management, 5, 9-22.

Chowdhary, R. (2017). Information Technology and its Impact on Development of Indian Banking System. Journal of Bank Management \& Financial Strategies, 1(2), 9-17.

Cook, W. D., Hababou, M., \& Roberts, G. S. (2000). The effects of financial liberalization on the Tunisian banking industry: A non-parametric approach. Revue of Industrial Economy, 29, 22-45.

Dos Santos, B., Peffers, G., \& Mauer, D. (1993). The impact of information technology investment announcements on the market value of the firm. Information Systems Research, 4, 1-23.

Entorf, H., Gollac, M., \& Kramarz, F. (1999). New Technologies, Wages and Worker Selection. Journal of Labor Economics, 17(3). 464-491.

Gayathri, G., \& Suvitha, K. V. (2018). Impact of Information Technology on the Profitability of Banks in India. International Journal of Pure and Applied Mathematics, 118(20), 225232.

Hermalin, B., \& Wallace, N. (1994). The Determinants of Efficiency and Solvency in Savings and Loans. Journal of Economics, 25, 361-381.

Hoque, M. A., Ahmad, A., Chowdhury, M. M., \& Shahidullah, M. (2020). Impact of Monetary Policy on Bank's Profitability: A Study on Listed Commercial Banks in Bangladesh. International Journal of Accounting \& Finance Review, 5(2), 72-79.

Isik, I., \& Hassan, M. K. (2002). Cost and Profit Efficiency of the Turkish Banking Industry: An Empirical Investigation. Financial Review, 37, 257-280.

Kupper, E.F. (1998). Risk Management in Banking. in: Risk and Capital Management, Proceedings of a conference on risk and capital management at H.C., Coombs Center for Financial Studies, Sydney, 25-38.

Landauer, T. (1995).The Trouble with Computers-Usefulness, Usability and Productivity. MIT Press, Cambridge. 
Licht, G., \& Moch, D. (1999). Innovation and information technology in services. Canadian Journal of Economics, 32(2), 48-61.

Loveman, G. (1994). An assessment of the productivity impact of information technologies. In Information Technology and the Corporation of the 1990s: Research Studies, edited by Thomas J. Allen and Michael S. Scott Morton, Oxford: Oxford University Press, 84110.

Molyneux, P., \& Thornton, J. (1992). Determinants of European Bank Profitability: A note. Journal of Banking and Finance, 16(6), 1173-1178.

Morrison, C., \& Berndt, R. (1990). Assessing the productivity of information technology equipments in the US manufacturing industries. Working paper $\mathrm{n}^{\mathrm{o}}$. 3582. National Bureau of Economic Research.

Ndeffo, L.N., \& Ningaye, P. (2007). Financial reforms and profitability of the banking system of the CEMAC States. African Economic Conference, 15-17. November, Addis Abeba, Ethiopia.

Oliner, S.D., \& Sichel, D.E. (2000).The Resurgence of Growth in the Late 1990s: Is Information Technology the Story?. Journal of Economic Perspectives, 14(4), 3-22.

Omri, A., \& Hachana, R. (2008). Investment in information technology and banking productivity: The case of Tunisian banks. 17th Association of Information and Management Conference, Nice, France.

Prasad, B., \& Harker, P. T. (1997). Examining the contribution of information technology toward productivity in US retail banking. Working paper, Wharton School, University of Pennsylvania.

Singh, S., \& Singh Brar, A. (2016). Information Technology in Indian Banking Sector: Some Recent Developments. International Conference on Recent innovations in Sciences, Management, Education and Technology, 4(7), 529-535

Smida, H., \& Ayadi, M. (2006). Savings in banking costs : The case of Tunisian deposit banks. Euro-mediterranean Economics and Finance Review, 1(4).

Solow, R. (1987). We'd better watch out. New York Times Book Review, p. 36.

Teru, S. P., Idoku, I., \& Ndeyati, J. T. (2017). A Review of the Impact of Accounting Information System for Effective Internal Control on Firm Performance. Indian Journal of Finance and Banking, 1(2), 52-59.

Thenet, G., \& Guillouzo, R. (2002). The conception of technology as a black box by bank management control : the measurement of the operational performance of branches by 
the DEA method. Rennes Laboratory of Economics and Social Sciences, University of Haute Bretagne, Rennes 2, 1-20.

Triplett, J.E. (1997). Concepts of Capital for Production Accounts and for Wealth Accounts: The Implications for Statistical Programs. International Conference on Capital Stock Statistics, Canberra, Australia, 10-14.

Yao, J.M. (2005). Econometric analysis of the determinants of the profitability of European banks. DEA Econometrics Finance Thesis, University Pantheon ASSAS Paris 2.

Zaghla, A., \& Boujelbene, Y. (2008). Explanatory factors of X-efficiency in the Tunisian Banks: A stochastic frontier approach. MPRA Munich Personal RePEc Archive, February, 124.

\section{Copyrights}

Copyright for this article is retained by the author(s), with first publication rights granted to the journal. This is an open-access article distributed under the terms and conditions of the Creative Commons Attribution license (http://creativecommons.org/licenses/by/4.0/) 